\title{
Do captive male meadow voles experience acute stress in response to weasel odour?
}

\author{
Q.E. Fletcher and R. Boonstra
}

\begin{abstract}
The hormonal stress response is adapted to deal with acute (short-term) stressors; however, chronic (long-term) stressors have negative effects on survival and fitness. Field and laboratory evidence suggest that voles respond behaviourally to predator odours. However, it is unknown whether voles mount an acute hormonal stress response to predator odour. We determined whether reproductively active, captive male meadow voles (Microtus pennsylvanicus (Ord, 1815)) mounted a more pronounced hormonal stress response to weasel odour (ermine, Mustela erminea L., 1758), one of their principal mammalian predators, than to nonpredator and control odours. We compared the corticosterone response of captive voles to weasel, jumping mouse (Zapus hudsonius (Zimmermann, 1780)), and control odours following acute (20 min) exposure. The hormonal stress response to the treatment odours did not differ, indicating that captive male voles in the reproductive season do not mount an acute stress response to predator odour. We hypothesize that voles do not respond to weasel odour because, independent of other stimuli, olfactory signals are not reliable enough to outweigh the costs, such as suppression of reproduction and reproductive behaviour, associated with a response.
\end{abstract}

Résumé : La réaction hormonale de stress est une adaptation pour résister à des facteurs aigus de stress de courte durée; par ailleurs, les facteurs chroniques (à long terme) de stress ont des effets négatifs sur la survie et la fitness. Des données de terrain et de laboratoire laissent croire que les campagnols ont des réactions comportementales aux odeurs des prédateurs. On ne sait pas cependant si les campagnols développent une réaction hormonale aiguë de stress en présence de l'odeur d'un prédateur. Nous avons déterminé si des campagnols de Pennsylvanie (Microtus pennsylvanicus (Ord, 1815)) mâles, actifs sexuellement et gardés en captivité, développent une réaction hormonale de stress plus prononcée à l'odeur d'hermine (Mustela erminea L., 1758), un de leurs plus importants mammifères prédateurs, par comparaison à leur réaction à des odeurs de non prédateurs ou d'odeurs témoins. Nous avons comparé la réaction de la corticostérone de campagnols en captivité aux odeurs d'hermines et de souris sauteuses (Zapus hudsonius (Zimmermann, 1780)) ainsi qu'à des odeurs témoins après une exposition aiguë $(20 \mathrm{~min})$. Les réactions hormonales de stress ne diffèrent pas d'un traitement à l'autre, ce qui indique que les campagnols mâles durant la saison de reproduction ne développent par de réaction aiguë de stress à l'odeur des prédateurs. Nous émettons l'hypothèse selon laquelle les campagnols ne réagissent pas à l'odeur des hermines, parce que, indépendamment des autres stimulus, les signaux olfactifs ne sont pas assez fiables pour contrecarrer les coûts, tels que la suppression de la reproduction et du comportement reproducteur, qui sont associés à la réaction.

[Traduit par la Rédaction]

\section{Introduction}

Predators can induce a stress response in their prey not only by physically attacking them but also by making them fearful of a potential attack. Stress is defined as a condition of arousal or excitability that occurs in response to an aversive stimulus (Kim and Diamond 2002). The stress response is a set of responses to potentially harmful environmental challenges that allows the organism to maximize its chances for short-term survival. This response is the classic "flight or fight" syndrome and is a generalized response to a wide variety of stressors. The first line of defense, occurring within seconds of the stressor, is that the sympathetic nervous system causes the adrenal medulla to release catechol-

Received 14 April 2005. Accepted 16 February 2006. Published on the NRC Research Press Web site at http://cjz.nrc.ca on 27 April 2006.

Q.E. Fletcher and R. Boonstra. ${ }^{1}$ Centre for the Neurobiology of Stress, Department of Life Sciences, University of Toronto at Scarborough, 1265 Military Trail, Scarborough, ON M1C 1A4, Canada.

${ }^{1}$ Corresponding author (e-mail: boonstra@utsc.utoronto.ca). amines (epinephrine and norepinephrine) into the circulatory system. The second line of defense (the focus of this paper), also occurring immediately, is the activation of the hypothalamic-pituitary-adrenal (HPA) axis, which results in the release of glucocorticoids from the adrenal cortex into the circulatory system within approximately $3 \mathrm{~min}$. Immediate catabolic effects of the glucocorticoids result in the mobilization of glucose for the muscles, the stimulation of hepatic gluconeogenesis (the breakdown of other body tissues such as protein), and the shunting of energy resources away from peripheral tissues and activities not needed for short-term survival (e.g., growth, reproduction, and digestion; Sapolsky et al. 2000). Cardiovascular tone is increased, immune function is stimulated, reproductive physiology and behaviour are suppressed, feeding and appetite are decreased, and cognition is sharpened. The HPA axis is adapted to deal with short-term stressors (e.g., predator attacks); however, chronic activation of the HPA axis, typified by high levels of glucocorticoids, is potentially deleterious, affecting long-term survival and fitness through infertility, impaired resistance to disease, steroid diabetes, digestive ulcers, and inhibition of growth (Sapolsky 2002; Wingfield and Sapolsky 2003). 
Prey often alter their behaviour in response to the auditory, visual, and chemosensory cues of their predators (Lima and Dill 1990; Kats and Dill 1998). Weasels are highly efficient predators that feed primarily on voles (Pearson 1985; Klemola et al. 1997). Predation by weasels can be so intense in some areas that it can drive vole population cycles (Korpimäki et al. 2002). Voles respond behaviourally to the odour of weasels and other predators, presumably to decrease the risk of predation. Weasel odour is known to reduce vole (Microtus spp.) foraging on agricultural crops (Sullivan et al. 1988). Microtus agrestis (L., 1761) and Microtus arvalis (Pallas, 1778) avoid entering traps tainted with weasel odour (Stoddart 1976; Gorman 1984). Furthermore, laboratory studies suggest that meadow voles (Microtus pennsylvanicus (Ord, 1815)) reduce their activity following exposure to fox odour (Perrot-Sinal et al. 1999, 2000). In additional laboratory studies, M. agrestis, $M$. arvalis, and Clethrionomys glareolus (Schreber, 1780) avoided areas tainted with weasel odour and exhibited reduced activity levels when they were exposed to weasel odour (Gorman 1984; Jędrzejewski et al. 1993; Ronkainen and Ylönen 1994).

We hypothesized that meadow voles perceive predator odour as a stressor and predicted that voles should mount an acute hormonal stress response to predator odour for the following reasons. First, the behaviours demonstrated by voles in response to predator odours in laboratory studies (Gorman 1984; Jędrzejewski et al. 1993; Ronkainen and Ylönen 1994) are similar to those shown by social (Günther's) voles (Microtus socialis (Pallas, 1773)) in response to tawny owl (Strix aluco L., 1758) calls, and in social voles these behaviours are accompanied by a hormonal stress response (Eilam et al. 1999). Second, another rodent, the laboratory rat (Rattus norvegicus (Berkenhout, 1769)), also mounts a hormonal stress response when it is exposed to predator odour (Morrow et al. 2000; Holmes and Galea 2002).

The purpose of this study was to examine the effects of acute exposure to predator odour on the hormonal stress response of reproductively active male meadow voles. Specifically, we addressed the question, Do voles mount a more pronounced acute stress response to weasel odour than to nonpredator and control odours? To answer this question, we brought free-ranging meadow voles into captivity and compared their baseline levels of corticosterone with levels after acute (20 min) exposure to weasel (ermine, Mustela erminea L., 1758), jumping mice (Zapus hudsonius (Zimmermann, 1780)), and control odours. Weasels and jumping mice are found in the same grasslands as meadow voles (Boonstra and Rodd 1983). We predicted that voles exposed to weasel odour would mount the most pronounced hormonal stress response.

\section{Materials and methods}

\section{Animals}

Breeding male meadow voles (35-59 g), distinguished by scrotal testes, were captured between 3 and 5 July 1991 in a grassland field at the Toronto International Airport (Ontario, Canada; site description in Boonstra and Rodd 1983). Their individual history and exposure to other species prior to cap- ture was unknown. Voles were maintained singly in large polypropylene cages $(45 \mathrm{~cm} \times 24 \mathrm{~cm} \times 12 \mathrm{~cm})$ on an $18 \mathrm{~h}$ light : $6 \mathrm{~h}$ dark cycle. Cages were provided with clean bedding chips and clean cotton for nesting material. Water and food (Purina Lab Chow and Purina Rabbit Chow, Purina, Mississauga, Ontario) were provided ad libitum. Females were not used because their reproductive cycle has major effects on corticosterone concentrations and it is difficult to standardize female reproductive state; therefore, it is difficult to compare the stress response among females or between females and males (Boonstra and Boag 1992).

Voles were assigned to one of three odour exposure treatments: (1) weasel odour $(n=10)$, (2) jumping mouse odour $(n=9)$, or $(3)$ control odour $(n=10)$. Animals were assigned to treatments in a stratified manner such that mean body mass was approximately equivalent across treatments (range of mean mass among groups at time of capture = 46.4-48.3 g). All of the voles were housed in the same room and all voles in a given treatment were held on one cage rack. We did not intersperse the vole cages from the three treatments because the odours that the voles were exposed to would have spread between treatments. The three racks were positioned parallel to each other and polyethylene plastic, fastened from floor to ceiling, separated the racks and prevented the passage of odours between treatments. Ventilation fans, positioned in the wall at either end of the laboratory room and operating in a push-pull method (the fan at one end pulled air out of the room and that at the other end drew air into the room), changed the air in the room 13 times per hour. The airflow was parallel to the cage racks, thus preventing cross contamination among treatments.

Five jumping mice and one weasel were live-trapped near Greenwood, Ontario, approximately $25 \mathrm{~km}$ northeast of Toronto. The jumping mice and the weasel were housed in separate buildings away from the voles. Jumping mice were maintained in the same manner as the voles. The weasel was housed in a $61 \mathrm{~cm} \times 61 \mathrm{~cm} \times 30.5 \mathrm{~cm}$ galvanized steel cage with a nest box and cotton for bedding and was fed dead voles. After completion of the experiment, all animals were released at their site of capture in the field. The University of Toronto animal care committee approved all procedures in accordance with the guidelines of the Canadian Council on Animal Care.

\section{Odour exposure and blood sampling}

Voles were habituated to laboratory conditions for at least $12 \mathrm{~d}$ and were then bled twice. First, a baseline (control) blood sample was collected from all individuals in a random order on 15 July. Second, acute odour exposure was done over $2 \mathrm{~d}$ to minimize both disturbance and the time between the start of the manipulation and blood collection. Voles in the jumping mouse odour treatment were tested on 18 July and voles in the control and weasel odour treatments were tested on 19 July. The acute odour exposure was achieved by taking faeces- and urine-soiled cotton bedding and hardwood chips from the donor animals' cages (jumping mouse and weasel) and placing them into the vole cages; unused, clean cotton bedding was used for the control odour. The material from both donor species was collected on the day it was needed. Material from jumping mice was pooled in a 
clean plastic bag and mixed thoroughly, and a handful was placed in the cage of each designated vole. Material from the weasel was placed in a clean plastic bag and mixed thoroughly, and a handful was placed in the cage of each designated vole. The addition of the foreign material to all the cages took approximately $7 \mathrm{~min}$. Twenty minutes after the last piece of material was added, blood was collected from the voles in a random order.

All blood samples $(80 \mu \mathrm{L})$ were obtained between 0800 and 0915 by puncturing the retro-orbital sinus using a heparinized pasteur pipette. Bradshaw (2003) has suggested that this bleeding method is the most efficient and least stressful means of collecting small blood samples. To minimize the stress experienced by voles in the holding room as a result of human noise, vole cages were carried one at a time from the holding room to a separate bleeding room, where the voles were bled. The maximum amount of time between when a vole's cage was picked up from the cage rack in the holding room and when a blood sample was obtained in the bleeding room was $1.5 \mathrm{~min}$. Carrying the voles in their cages to the bleeding room presumably would have been stressful for the voles; however, levels of corticosterone in the plasma would not have been elevated as a result of this stressor because all of the blood samples were obtained well before the stress-related surge of glucocorticoids would have been released into general circulation (3 $\mathrm{min}$ after the initiation of the stress response) (Seggie and Brown 1975; Redei et al. 1994). To further minimize human noise in the holding room, the cages were not returned to the holding room until after all voles had been bled. Blood was kept on ice until all samples had been collected and was then centrifuged at $8800 \mathrm{~g}$ for $4 \mathrm{~min}$ in an Eppendorf Micro Centrifuge. The separated plasma was then stored at $-70{ }^{\circ} \mathrm{C}$ until it was analyzed for levels of corticosterone.

\section{Hormone assays}

Most corticosterone in blood is normally bound to a carrier protein, corticosteroid binding globulin $(\mathrm{CBG})$, the primary protein that binds corticosterone in the plasma (Rosner 1990; Breuner and Orchinik 2002). Only the corticosterone in the plasma that is not bound to $\mathrm{CBG}$ is biologically active. Corticosteroid assays involved measurements of total plasma corticosterone and CBG using the procedures given in Boonstra and Boag (1992). The intra- and inter-assay coefficients of variation for corticosterone were $10 \%$ and $16 \%$, respectively. $\mathrm{CBG}$ was measured as the maximum corticosterone binding capacity (MCBC).

\section{Statistical analysis}

All statistical analyses were performed using STATISTICA $^{\circledR}$ software (StatSoft Inc. 2001). All data met the assumption of homogeneity of variances according to Cochran's test (Day and Quinn 1989) and are plotted as means \pm SE. Data were analyzed using a repeated-measures analysis of variance (ANOVA). This analysis takes into account the fact that the repeated measures from an individual are not independent and tests for treatment effects associated with differences observed within subjects (Keppel 1982). We tested for ( $i$ ) differences in the response to odour treatment (weasel, jumping mouse, and control), (ii) differences over time in the response to odour exposure (pre-exposure baseline levels and acute $(20 \mathrm{~min})$ exposure), and (iii) an interaction between the two. The null hypothesis was rejected at $P<0.05$. We used Tukey's multiple comparison post-hoc test to examine the significance of between-subjects effects.

\section{Results}

The two-way ANOVA on MCBC (odour treatment $\times$ time) indicated no odour treatment effect $\left(F_{[2,26]}=0.3, P=0.75\right)$, no time effect $\left(F_{[1,26]}=0.6, P=0.44\right)$, and no interaction effect $\left(F_{[2,26]}=0.4, P=0.70\right)$. The absence of any difference in MCBC indicates that the amount of free corticosterone (the biologically active form of the steroid) was comparable across groups and that the total corticosterone values presented below reflect actual differences in the magnitude of the corticoid signal in circulation (Issa et al. 1990).

The two-way ANOVA on total corticosterone concentrations (odour treatment $\times$ time) indicated no odour treatment effect $\left(F_{[2,26]}=0.1, P=0.90\right)$, a strong trend toward a time effect $\left(F_{[1,26]}=4.2, P=0.05\right)$, and no interaction effect $\left(F_{[2,26]}=0.6, P=0.56\right)$. Thus, total corticosterone concentrations were higher after the acute exposure compared with concentrations at the baseline bleed, irrespective of the odour treatment (Fig. 1). Overall, the levels of corticosterone that we recorded (overall average over all treatments and bleeds = $405 \mathrm{ng} / \mathrm{mL}$ ) were higher than those found in laboratory-bred meadow voles (total corticosterone $=\sim 275 \mathrm{ng} / \mathrm{mL}$; Klein and Nelson 1999) and in wild-caught voles (329 ng/mL; Boonstra and Boag 1992) but lower than those in another laboratory study (504 ng/mL; Seabloom 1965).

\section{Discussion}

Even though weasels are voracious predators of meadow voles and they occur in the area where the voles for this experiment were collected, captive male voles in the reproductive season did not mount a more pronounced acute stress response to weasel odour than to nonpredator and control odours (Fig. 1). Three caveats must be considered before discussing these results. First, we exposed voles to the odour of only one weasel. As a result, the voles exposed to weasel odour were not true replicates and thus the experiment was pseudoreplicated (Hurlbert 1984; Kroodsma et al. 2001). We did not expose voles to the odour of multiple weasels because the active component that rodents respond to is secreted by every weasel and it is so similar between weasels that it has been isolated, synthetically manufactured, and shown to deter voles from foraging on agricultural crops (Sullivan et al. 1988).

Second, it is possible that voles mount a hormonal stress response to weasel odour when they are in their natural environment but that a type II statistical error prevented us from detecting this response in our experiment. A lack of statistical power may have led to a type II error. The corticosterone response to predator odour has been examined in five experiments on laboratory rats. The percent increase in corticosterone values in response to predator odour exposure is highly variable (Perrot-Sinal et al. 1999, 34\% increase, $n=24$; Morrow et al. 2000, 363\% increase, $n=6$; Tanapat et al. 2001, $123 \%$ increase, $n=5$; Holmes and Galea 
Fig. 1. Total corticosterone levels obtained from repeatedly sampling meadow voles (Microtus pennsylvanicus) exposed to (1) control, (2) weasel (Mustela erminea), and (3) jumping mouse (Zapus hudsonius) odours. Samples sizes of these three treatments were 10, 10 , and 9, respectively. Baseline levels were determined 3-4 d before the voles were exposed to odour. Acute odour exposure samples were obtained after the voles in the three treatments had been exposed to odoriferous material for $20 \mathrm{~min}$.

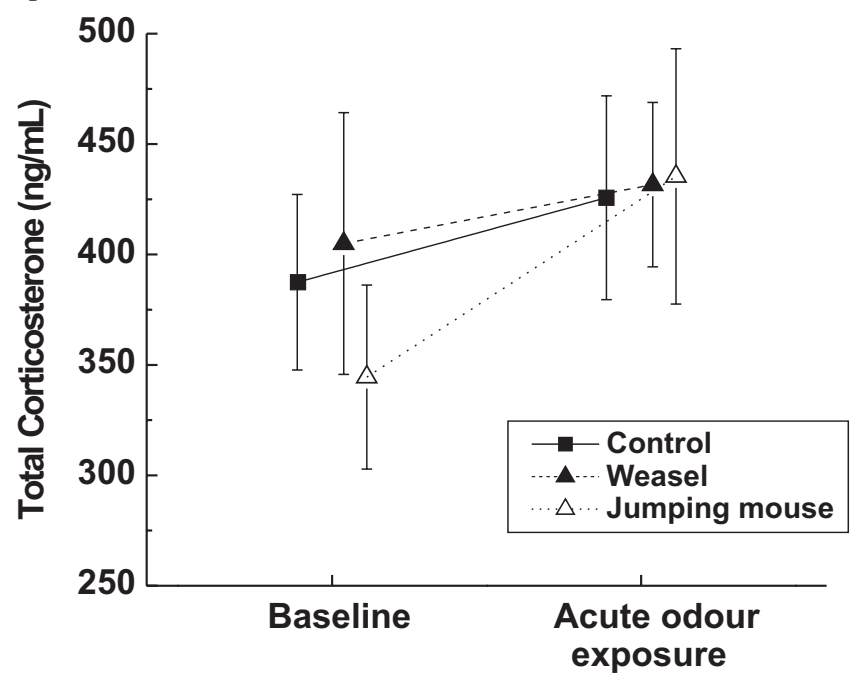

2002, 46\% increase, $n=12$; Falconer and Galea 2003, $80 \%$ increase, $n=3$ ). Using the formulas outlined in Cohen (1977) and the program developed by Dupont and Plummer (1998), we found that the power to detect a significant corticosterone response to weasel odour using highly conservative parameters $(\alpha=0.05$ (two-tailed), a corticosterone increase of $34 \%$ (Perrot-Sinal et al. 1999), $\sigma=152.9 \mathrm{ng} / \mathrm{mL}$ (overall $\sigma$ for the individuals in the weasel group), and $r=$ 0.6 (average $r$ for the individuals in all three groups, $0.6 \pm$ 0.07)) was 0.85. Cohen (1977) suggested that power $=0.8$ is a desired value; therefore, we had enough power to detect a response to weasel odour.

Third, a type II error may also have been committed if levels of corticosterone in all treatment groups were elevated before the voles were exposed to odour, making it impossible to detect a difference between the odour exposure treatments. This may have occurred in three different ways. First, if the voles were experiencing chronic stress as a result of being in captivity, then their baseline levels of corticosterone may have been upregulated. However, when laboratory rats are chronically stressed, a novel stressor continues to elicit a strong stress response (Aguilera 1998). This suggests that voles would not have been precluded from mounting a stress response to odour even if they were stressed as a result of being in captivity. Second, when the three treatments were pooled, there was a strong trend for levels of corticosterone in the acute exposure sample to be greater than levels in the baseline sample. This likely resulted from the voles being mildly stressed by the disturbance caused by adding foreign material to their cages $20 \mathrm{~min}$ before they were bled. This mild stress response also would not have prevented us from detecting a difference between the groups because if weasel odour was stressful, it would have increased the intensity of the stressor the voles were experiencing and thus it would have led to a more pronounced stress response (Dallman et al. 1987). Third, levels of corticosterone show a pronounced circadian rhythm (Dallman et al. 1987) and can fluctuate up to $77 \%$ around the $24 \mathrm{~h}$ mean (Seabloom 1965). We collected blood samples between 0800 and 0915; therefore, levels of corticosterone would have been near the circadian nadir that occurs around 0700 (Seabloom 1965). However, even if levels of corticosterone were quantified during the circadian peak, past research suggests that the voles would not have been precluded from mounting a stress response (Dallman et al. 1987). As a result, the most parsimonious interpretation of our results is that voles do not mount a hormonal stress response to weasel odour.

We propose that the most likely explanation for our results is that voles do not mount a hormonal response to predator odour because odour, in the absence of other stimuli, is not a reliable indicator of immediate predation risk (Orrock et al. 2004). If voles mounted a hormonal response every time they were exposed to predator odour, they would experience chronic stress that would negatively affect survival and suppress reproduction (Arnold and Dittami 1997; Boonstra et al. 1998; Wingfield and Sapolsky 2003). On the other hand, it is adaptive to mount a hormonal and a behavioural response to visual cues because they are reliable signals (Blumstein 2002) and both responses are required to escape an imminent attack (Sapolsky 2002). Columbian ground squirrels (Spermophilus columbianus (Ord, 1815)) respond hormonally and experience chronic stress when they are repeatedly exposed to a barking dog (Hubbs et al. 2000). Blanchard et al. (1998) found that laboratory rats experience chronic stress when they are repeatedly exposed to a live cat. Auditory stimuli may also be reliable in some cases because recordings of tawny owls elicit both a behavioural and a hormonal response in Günther's voles (Eilam et al. 1999). In this case, auditory cues are probably as reliable as visual cues because they confirm that an owl is in the immediate vicinity.

An emerging view is that small mammals do not mount a strong behavioural response to predator odour. Past research has demonstrated that small mammals mount a behavioural response when they are put in close proximity to odour under laboratory conditions (Jędrzejewski et al. 1993). It has also consistently been shown that small mammals avoid entering traps tainted with predator odour (Gorman 1984). However, it has been argued that this research does not accurately depict how animals use the cues from odour to avoid predators in the real world (Korpimäki and Krebs 1996; Jonsson et al. 2000; Powell and Banks 2004). Research conducted under more natural conditions has shown that small mammals do not avoid foraging in areas tainted with predator odour (Pusenius and Ostfeld 2002; Orrock et al. 2004; Powell and Banks 2004). Moreover, this research suggests that small mammals use indirect cues of predation risk, such as the amount of vegetative cover, rather than the cues they obtain from predator odours to assess the risk of predation. The overall picture that emerges from this research is that the response to predator odour is not as strong as was suggested by early research and that odour is only part of the integrative picture that animals use to assess predation risk. Their response to odour appears to be dependent 
on a number of factors including their sex (Jędrzejewski and Jędrzejewska 1990), their density (Sullivan et al. 1988; Sullivan et al. 2004), and the season (Herman and Valone 2000). As a result, given that small mammals respond behaviourally to predator odour only under restricted conditions, perhaps it is not that surprising that the voles in our study did not mount a hormonal response to predator odour.

In conclusion, our results indicate that captive male voles in the reproductive season do not mount a hormonal response to weasel odour. We hypothesize that voles do not mount a hormonal response because odour on its own is not reliable enough to warrant the costs associated with a hormonal response. However, future research should address whether or not voles experience chronic stress and the associated fitness costs when they are in their natural environment and are exposed to high levels of predation risk assessed through a combination of visual, auditory, and olfactory cues of their predators. Snowshoe hares (Lepus americanus (Erxleben, 1777) experience chronic stress and the associated fitness costs when exposed to high levels of predation risk (Boonstra et al. 1998). Moreover, our project did not address whether or not voles mount a hormonal response to odour at other times throughout the year. A response during the breeding season may be inhibited because of the negative effects of stress on the reproductive axis (Wingfield and Sapolsky 2003) or because the missed opportunity costs associated with responding to predator odour are more pronounced during the breeding season (e.g., avoiding a patch food or a receptive mate; Bouskila and Blumstein 1992; Blumstein 2002). Future research is required to determine whether there are seasonal changes in the propensity of voles to respond to predator odour.

\section{Acknowledgements}

We thank Lily Lu for help with the radioimmunoassays. We thank R.M. Brigham, M. Clinchy, K.A. Edwards, and K. Magnusson for helpful comments that greatly improved the manuscript. This work was funded by a Natural Sciences and Engineering Research Council of Canada operating grant awarded to R.B.

\section{References}

Aguilera, G. 1998. Corticotropin releasing hormone, receptor regulation and the stress response. Trends Endocrinol. Metab. 9: 329-336.

Arnold, W., and Dittami, J. 1997. Reproductive suppression in male alpine marmots. Anim. Behav. 53: 53-66. doi:10.1006/ anbe.1996.0277.

Blanchard, R.J., Nikulina, J.N., Sakai, R.R., McKittrick, C., McEwen, B., and Blanchard, D.C. 1998. Behavioral and endocrine change following chronic predatory stress. Physiol. Behav. 63: 561-569. doi:10.1016/S0031-9384(97)00508-8. PMID: 9523899.

Blumstein, D.T. 2002. Moving to suburbia: ontogenetic and evolutionary consequences of life on predator-free islands. J. Biogeogr. 29: 685-692. doi:10.1046/j.1365-2699.2002.00717.x.

Boonstra, R., and Boag, P.T. 1992. Spring declines in Microtus pennsylvanicus and the role of steroid hormones. J. Anim. Ecol. 61: 339-352.

Boonstra, R., and Rodd, F.H. 1983. Regulation of breeding density in Microtus pennsylvanicus. J. Anim. Ecol. 52: 757-780.

Boonstra, R., Hik, D., Singleton, G.R., and Tinnikov, A. 1998. The impact of predator-induced stress on the snowshoe hare cycle. Ecol. Monogr. 79: 371-394.

Bouskila, A., and Blumstein, D.T. 1992. Rules of thumb for predation hazard assessment - predictions from a dynamic model. Am. Nat. 139: 161-176. doi:10.1086/285318.

Bradshaw, D. 2003. Vertebrate ecophysiology — an introduction to its principles and applications. Cambridge University Press, Cambridge.

Breuner, C.W., and Orchinik, M. 2002. Plasma binding proteins as mediators of corticosteroid action in vertebrates. J. Endocrinol. 175: 99-112. doi:10.1677/joe.0.1750099. PMID: 12379494.

Cohen, J. 1977. Statistical power analysis for the behavioral sciences. Revised ed. Academic Press, New York.

Dallman, M.F., Akana, S.F., Cascio, C.S., Darlington, D.N., Jacobson, L., and Levin, N. 1987. Regulation of ACTH secretion: variations on a theme of B. Recent Prog. Horm. Res. 43: 113-173. PMID: 2819993.

Day, R.W., and Quinn, G.P. 1989. Comparisons of treatments after an analysis of variance in ecology. Ecol. Monogr. 59: 433-463.

Dupont, W.D., and Plummer, W.D. 1998. Power and sample size calculations for studies involving linear regression. Control. Clin. Trials, 19: 589-601. PMID: 9875838.

Eilam, D., Dayan, T., Ben-Eliyahu, S., Schulman, I., Shefer, G., and Hendrie, C.A. 1999. Differential behavioural and hormonal responses of voles and spiny mice to owl calls. Anim. Behav. 58: 1085-1093. doi:10.1006/anbe.1999.1224. PMID: 10564611.

Falconer, E.M., and Galea, L.A.M. 2003. Sex differences in cell proliferation, cell death and defensive behavior following acute predator odor stress in adult rats. Brain Res. 975: 22-36. doi:10.1016/S0006-8993(03)02542-3. PMID: 12763590.

Gorman, M.L. 1984. The response of prey to stoat (Mustela erminea) scent. J. Zool. 202: 419-423.

Herman, C.S., and Valone, T.J. 2000. The effect of mammalian predator scent on the foraging behavior of Dipodomys merriami. Oikos, 91: 139-145. doi:10.1034/j.1600-0706.2000.910113.x.

Holmes, M.M., and Galea, L.A.M. 2002. Defensive behavior and hippocampal cell proliferation: differential modulation by naltrexone during stress. Behav. Neurosci. 116: 160-168. doi:10. 1037/0735-7044.116.1.160. PMID: 11898802.

Hubbs, A.H., Millar, J.S., and Wiebe, J.P. 2000. Effect of brief exposure to a potential predator on cortisol concentrations in female Columbian ground squirrels (Spermophilus columbianus). Can. J. Zool. 78: 578-587. doi:10.1139/cjz-78-4-578.

Hurlbert, S.H. 1984. Pseudoreplication and the design of ecological field experiments. Ecol. Monogr. 54: 187-211.

Issa, A.M., Rowe, W., Gauthier, S., and Meaney, M.J. 1990. Hypothalamic-pituitary-adrenal activity in aged, cognitively impaired and cognitively unimpaired rats. J. Neurosci. 10: 3247-3254.

Jędrzejewski, W., and Jędrzejewska, B. 1990. Effect of a predator's visit on the spatial distribution of bank voles: experiments with weasels. Can. J. Zool. 68: 660-666.

Jędrzejewski, W., Rychlik, L., and Jędrzejewska, B. 1993. Responses of bank voles to odours of seven species of predators: experimental data and their relevance to natural predator-vole relationships. Oikos, 68: 251-257.

Jonsson, P., Koskela, E., and Mappes, T. 2000. Does risk of predation by mammalian predators affect the spacing behaviour of rodents? Two large-scale experiments. Oecologia, 122: 487-492. doi:10.1007/s004420050970.

Kats, L.B., and Dill, L.M. 1998. The scent of death: chemosensory assessment of predation risk by prey animals. Ecoscience, 5: 361-394.

Keppel, G. 1982. Design and analysis: a researcher's handbook. 2nd ed. Prentice-Hall Inc., Englewood Cliffs, N.J. 
Kim, J.J., and Diamond, D.M. 2002. The stressed hippocampus, synaptic plasticity and lost memories. Nat. Rev. Neurosci. 3: 453462. PMID: 12042880.

Klein, S.L., and Nelson, R.J. 1999. Activation of the immuneendocrine system with lipopolysaccharide reduces affiliative behaviors in voles. Behav. Neurosci. 113: 1042-1048. doi:10.1037/ 0735-7044.113.5.1042. PMID: 10571486.

Klemola, T., Koivula, M., Korpimäki, E., and Norrdahl, K. 1997. Small mustelid predation slows population growth of Microtus voles: a predator reduction experiment. J. Anim. Ecol. 66: 607614.

Korpimäki, E., and Krebs, C.J. 1996. Predation and population cycles of small mammals. Bioscience, 46: 754-764.

Korpimäki, E., Norrhahl, K., Klemola, T., Pettersen, T., and Stenseth, N.C. 2002. Dynamic effects of predators on cyclic voles: field experimentation and model extrapolation. Proc. R. Soc. Lond. B Biol. Sci. 269: 991-997.

Kroodsma, D.E., Byers, B.E., Goodale, E., Johnson, S., and Liu, W. 2001. Pseudoreplication in playback experiments, revisited a decade later. Anim. Behav. 61: 1029-1033. doi:10.1006/anbe. 2000.1676.

Lima, S.L., and Dill, L.M. 1990. Behavioral decisions made under the risk of predation: a review and prospectus. Can. J. Zool. 68: 619-640.

Morrow, B.A., Redmond, A.J., Roth, R.H., and Elsworth, J.D. 2000. The predator odor, TMT, displays a unique, stress-like pattern of dopaminergic and endocrinological activation in the rat. Brain Res. 864: 146-151. doi:10.1016/S0006-8993(00) 02174-0. PMID: 10793199.

Orrock, J.L., Danielson, B.J., and Brinkerhoff, R.J. 2004. Rodent foraging is affected by indirect, but not by direct, cues of predation risk. Behav. Ecol. 15: 433-437. doi:10.1093/beheco/arh031.

Pearson, O.P. 1985. Predation. In Biology of New World Microtus. Edited by R.H. Tamarin. The American Society of Mammalogists, Boston, Mass. pp. 535-566.

Perrot-Sinal, T.S., Ossenkopp, K.-P., and Kavaliers, M. 1999. Effects of repeated exposure to fox odor on locomotor activity levels and spatial movement patterns in breeding male and female meadow voles (Microtus pennsylvanicus). J. Chem. Ecol. 25: 1567-1583. doi:10.1023/A:1020836832455.

Perrot-Sinal, T.S., Ossenkopp, K.-P., and Kavaliers, M. 2000. Influence of a natural stressor (predator odor) on locomotor activity in the meadow vole (Microtus pennsylvanicus): modulation by sex, reproductive condition and gonadal hormones. Psychoneuroendocrinology, 25: 259-276. doi:10.1016/S0306-4530(99) 00054-2. PMID: 10737697.

Powell, F., and Banks, P.B. 2004. Do house mice modify their foraging behaviour in response to predator odours and habitat? Anim. Behav. 67: 753-759. doi:10.1016/j.anbehav.2003.08.016.

Pusenius, J., and Ostfeld, R.S. 2002. Effects of stoat's presence and auditory cues indicating its presence on tree seedling predation by meadow voles. Oikos, 91: 123-130. doi:10.1034/j.16000706.2000.910111.x.

Redei, E., Li, L.F., Halasz, I., McGivern, R.F., and Aird, F. 1994. Fast glucocorticoid feedback inhibition of ACTH secretion in the ovariectomized rat: effect of chronic estrogen and progesterone. Neuroendocrinology, 60: 113-123. PMID: 7969768.

Ronkainen, H., and Ylönen, H. 1994. Behaviour of cyclic bank voles under risk of mustelid predation: do females avoid copulations? Oecologia, 97: 377-381.

Rosner, W. 1990. The functions of corticosteroid-binding globulin and sex hormone-binding globulin: recent advances. Endocr. Rev. 11: 80-91. PMID: 2180689.

Sapolsky, R.M. 2002. Neuroendocrinology of the stress response. In Behaviorial endocrinology. Edited by J.B. Becker, S.M. Breedlove, D. Crews, and M.M. McCarthy. 2nd ed. MIT Press, Cambridge, Mass. pp. 409-450.

Sapolsky, R.M., Romero, L.M., and Munck, A.U. 2000. How do glucocorticoids influence stress responses? Integrating permissive, suppressive, stimulatory, and preparative actions. Endocr. Rev. 21: 55-89. doi:10.1210/er.21.1.55. PMID: 10696570.

Seabloom, R.W. 1965. Daily motor activity and corticosterone secretion in the meadow vole. J. Mammal. 46: 286-295.

Seggie, J.A., and Brown, G.M. 1975. Stress response patterns of plasma corticosterone, prolactin, and growth hormone in rat, following handling or exposure to novel environment. Can. J. Physiol. Pharmacol. 53: 629-637. PMID: 1175088.

StatSoft Inc. 2001. STATISTICA ${ }^{\circledR}$ for Windows. Version 6 [computer program]. StatSoft Inc., Tulsa, Okla.

Stoddart, D.M. 1976. Effect of the odour of weasels (Mustela nivalis L.) on trapped samples of their prey. Oecologia, 22: 439-441. doi:10.1007/BF00345320.

Sullivan, T.P., Crump, D.R., and Sullivan, D.S. 1988. Use of predator odors as repellents to reduce feeding damage by herbivores. III. Montane and meadow voles (Microtus montanus and Microtus pennsylvanicus). J. Chem. Ecol. 14: 363-377. doi:10. 1007/BF01022552.

Sullivan, T.P., Sullivan, D.S., Reid, D.G., and Leung, M.C. 2004. Weasels, voles, and trees: influence of mustelid semiochemicals on vole populations and feeding damage. Ecol. Appl. 14: 9991015.

Tanapat, P., Hastings, N.B., Rydel, T.A., Galea, L.A.M., and Gould, E. 2001. Exposure to fox odor inhibits cell proliferation in the hippocampus of adult rats via an adrenal hormone-dependent mechanism. J. Comp. Neurol. 437: 496-504. doi:10.1002/cne. 1297. PMID: 11503148.

Wingfield, J.C., and Sapolsky, R.M. 2003. Reproduction and resistance to stress: when and how. J. Neuroendocrinol. 15: 711-724. PMID: 12834431. 